\title{
Short-term study shows that phytate-mineralizing rhizobacteria inoculation affects the biomass, phosphorus (P) uptake and rhizosphere properties of cereal plants
}

\author{
O. A. Martínez ${ }^{1,2}$, D. E. Crowley ${ }^{3}$, M. L. Mora ${ }^{4}$, and M. A. Jorquera ${ }^{4 *}$ \\ ${ }^{1}$ Instituto de Bioquímica y Microbiología, Facultad de Ciencias, Universidad Austral de Chile, Campus \\ Isla Teja, Valdivia, Chile. ${ }^{2}$ Programa de Doctorado en Ciencias de Recursos Naturales, Universidad de \\ La Frontera, Temuco, Chile ${ }^{3}$ Department of Environmental Sciences, University of California, Riverside, \\ CA 92521, USA. ${ }^{4}$ Center of Plant, Soil Interaction and Natural Resources Biotechnology, Scientific and \\ Technological Bioresource Nucleus, Universidad de La Frontera, Temuco, Chile. *Correspondence author: \\ milko.jorquera@ufrontera.cl
}

\begin{abstract}
Cereal production in southern Chile is based on volcanic soils (Andisol) that are phosphorus (P) deficient for plant nutrition. Phytate-mineralizing rhizobacteria (PMR) have been suggested as soil inoculants to improve $\mathrm{P}$ uptake and growth of plants cultivated in P-deficient soils. In this study, a greenhouse experiment was conducted to investigate the effects of inoculation with PMR (Bacillus sp. N1-19NA, Enterobacter sp. N029PA, Pseudomonas sp.N1-55PA and Serratia sp. N0-10LB) on biomass and P uptake of cereal plants (wheat, oat and barley) grown in a Chilean Andisol with out $\mathrm{P}$ fertilization. Results showed that inoculation with Enterobacter sp. N0-29PA significantly $(P \leq 0.05)$ increased the biomass and Puptake of oat plants. Changes in rhizosphere properties as soil enzyme activities (acid phosphatase and urease), and auxin production potential were also produced by Enterobacter sp. N0-29PA inoculation. Despite the possible value, Enterobacter sp. N029PA as a soil inoculant for P-deficient soils, other PMR assayed did not consistently enhanced biomass and P uptake of plants. In addtion, polymerase chain reaction-denaturing gradient gel electrophoresis (PCR-DGGE) combined with non-metric multidimensional scaling (nMDS) analysis revealed that PMR inoculation induced changes in rhizobacterial community composition, suggesting that PMR application substantially modify the microbiological characteristics of rhizosphere. However, long-term studies at field level are still needed to practical use of PMR as inoculants in Chilean Andisols.
\end{abstract}

Keywords: Cereal, phosphorus, phytate, rhizobacteria, rhizosphere, volcanic soil 


\section{Introduction}

Cereal production in southern Chile is established on ash-derived volcanic soils known as Andisols. Cultivated Chilean Andisols that have been fertilized often contain high amounts of total phosphorus (P), most of which is unavailable to plants due to the high rate of P fixation that occurs in soils having a low pHand high aluminum (Al) content (Mora and Canales, 1995; Borie and Rubio, 2003). To overcome this limitation, $\mathrm{P}$ based fertilizers must therefore be applied regularly to meet the $\mathrm{P}$ requirements of plants grown in these soils. In this context, there is considerable interest in possible methods to remobilize the chemically fixed phosphate by means of phosphate-solubilizing rhizobacteria (PSR), which can enhance P uptake and plant growth through production of organic acids that dissolve iron and $\mathrm{Al}$ phosphates (Richardson and Simpson, 2011). In addition to aluminum phosphate minerals, Chilean Andisols also contain high contents of organic $\mathrm{P}(\mathrm{Po})(>60 \%$ of total $\mathrm{P})$, primarily in the form of phytate (42-67\% of organic P) (Borie and Rubio, 2003), which represents an important pool of potentially available Pin Chilean Andisols (MenezesBlackburn et al., 2013). Therefore, the application of rhizobacteria that canhydrolize and mobilize this fixed Popool could be a useful strategy to streng then the $\mathrm{P}$ nutrition in plants and decrease the requirement for use of $\mathrm{P}$ based fertilizers in Chilean Andisols.

Phytate-mineralizing rhizobacteria (PMR) play a fundamental role in the mobilization and recycling of phytate from soil P reserves (Richardson and Simpson, 2011). PMR have been isolated from the rhizosphere of pasture and cereal plants grown in Chilean Andisols and their potential use as soil inoculants to increase $\mathrm{P}$ availability in Chilean Andisols has been investigated (Jorquera et al., 2008, 2011). PMR not only have the ability to mobilize $\mathrm{P}$ from insoluble forms of Pi and
Po but also commonly carry other traits involved in plant growth promotion, such as the production of indole acetic acid (IAA) (Acuña et al., 2011; Martínez et al., 2011). The phytohormone IAA enhances the development of the plant root system and may indirectly improve P uptake by plants (Marschner et al., 2011). However, the effect of PMR on P uptake, growth and fitness of plants cultivated in P-deficient soils remains unknown, especially in Chilean Andisols, and major studies are required to elucidate their efficacy as a partial substitute for $\mathrm{P}$ fertilizer application. Thus, the objective of this research wasto investigates the effect of previously isolated PMR on biomass and $\mathrm{P}$ uptake of cereal plants grown in a Chilean Andisol under P deficiency.

\section{Materials and Methods}

\subsection{Strains}

Bacillus sp. N1-19NA, Enterobacter sp. N0-29PA, Pseudomonas sp. N1-55PA and Serratia sp. N010LB, were previously isolated from rhizosphere soil and selected for their abilities to mineralize phytate (phytic acid dodecasodium salt hydrate), solubilize phosphate (tricalcium phosphate), and produce auxinlike substances (Martínez et al., 2011).

\subsection{Soil}

The soil selected for this research was an Andisol belonging to the Piedras Negras (PN) series, which contains high total $\mathrm{P}$, most of which is unavailable to plants as determinated by $\mathrm{P}_{\text {Olsen }}$ method (see below). This soil has been used as a model for studies on P-deficiency in southern Chile (Paredes et al., 2011), 
and regular applications of $\mathrm{P}$ fertilizers are required to sustain the crop productivity. The soil samples were collected from the top $20 \mathrm{~cm}$ of the soil profile inthe Osorno province of southern Chile ( $40^{\circ} 20^{\circ} \mathrm{S}$; $\left.72^{\circ} 35^{\prime} \mathrm{W}\right)$. Soil was air-dried and passed through a 2-mm sieve to homogenize the samples. Fractionation of soil P yielded ( $\left.\mathrm{mg} \mathrm{kg}^{-1}\right)$ : total $\mathrm{P}(\mathrm{Pt}) 1124$, inorganic $\mathrm{P}$ (Pi) 131 and organic $\mathrm{P}(\mathrm{Po})$ 993, $\mathrm{P}_{\text {Olsen }}$ 3. Other chemical properties indicated a K content of $109 \mathrm{mg}$ $\mathrm{kg}^{-1}, \mathrm{pH}_{\mathrm{H} 20} 5.4$, organic matter $17 \%$ and $\mathrm{Al}$ saturation $15.2 \%$, cation exchange capacity $2.95 \mathrm{cmol}+\mathrm{kg}^{-1}$.

\subsection{Greenhouse experiment}

A greenhouse experiment was conducted to evaluate the effects of PMR on biomass and P uptake of cereal plants without $\mathrm{P}$ fertilization. Similar economicrelevant cereal plants (wheat, Triticum aestivum L. cv. Fritz; oat, Avena sativa L. cv. Rayen; barley, Hordeum vulgare L. cv. Pincoya) were used in this assay. The data were complemented with measurements of diverse rhizosphere properties, such as root-surface phosphatase activity, phosphorus availability, auxin production potential, soil enzyme activities (urease and acid phosphatase) and bacterial community structure.

Firstly, cereal plants were germinated on wet filter paper for $7 \mathrm{~d}$, after which 10 seedlings were transplanted per pot containing $0.95 \mathrm{~kg}$ of the PN soil. Each plant was inoculated with one milliliter of PMR suspension $\left(\sim 1 \times 10^{9} \mathrm{cfu} \mathrm{mL}^{-1}\right)$ at 1,30 and 55 days (Fernández et al., 2007), and periodically irrigated to maintain $60 \%$ of the maximum water holding capacity. The inoculation treatments included: (1) control (uninoculated), (2) Bacillus sp. N1-19NA, (3) Enterobacter sp.N0-29PA, (4) Pseudomonas sp. N155PA, and (5) Serratia sp. N0-10LB. The plants were maintained under greenhouse conditions for 75 days and $\mathrm{N}$ fertilization (200 kg urea ha-1) was carried out at day-30.No P fertilization was applied.

The assays were carried out in completely randomized design, and the data were analyzed statistically with one-way ANOVA and LSD (least significant differences) post hoc test using JMP statistical software (SAS Institute, Inc.). Differences with $P \leq 0.05$ were considered significant.

\subsection{Plant biomass and P uptake}

Plants were carefully removed from the pots and washed with distilled water toremove soil adhering to the roots. The plants were then dried at $65^{\circ} \mathrm{C}$ for $48 \mathrm{~h}$ to determine total plant biomass as dry weight $\left(\mathrm{kg} \mathrm{pot}^{-1}\right)$. After plant dry biomass determination, the $\mathrm{P}$ contents $\left(\mathrm{mg} \mathrm{kg}^{-1}\right)$ in the plant tissues were analyzed by the molybdovanadate method as described by Sadzawka et al. (2007). Briefly, the samples were dryashed in a muffle furnace at $500{ }^{\circ} \mathrm{C}$ for $8 \mathrm{~h}$ and digested with $2 \mathrm{M} \mathrm{HCl}$. The acid digests were filtered and $\mathrm{P}$ in the extracts was quantified by spectrophotometry at $466 \mathrm{~nm}$ using a premeasured calibration curve to determine $\mathrm{P}$ content. Finally, the $\mathrm{P}$ uptake (mg pot- $\left.{ }^{1}\right)$ was estimated as $\mathrm{P}$ content $\left(\mathrm{mg} \mathrm{kg}^{-1}\right) \times$ plant dry biomass $\left(\mathrm{kg} \mathrm{pot}^{-1}\right)$.

\subsection{Rhizosphere properties}

\subsubsection{Phosphorus availability}

Plant available $\mathrm{P}$ in the rhizosphere soil was estimated by $\mathrm{P}_{\text {Olsen }}$ method as described by Sadzawka et al. (2006). Briefly, available P was extracted from rhizospheric soil with a bicarbonate $\left(\mathrm{NaHCO}_{3}\right)$ solution at $\mathrm{pH} 8.50$. Phosphorus in the extracts was quantitatively measured at $880 \mathrm{~nm}$ by a formation of an antimony-phosphate-molybdate complex reduced with ascorbic acid to form a blue-colored complex. 


\subsubsection{Root surface phosphatase activity}

Root surface phosphatase activity was determined according to the procedure described by Rubio et al. (1990) and Paredes et al. (2011), which uses $p$-nitrophenyl phosphate ( $p$-NPP) substrate to measure enzyme activity. Roots were submerged in $p$-NPP solution and incubated at $20^{\circ} \mathrm{C}$ for $30 \mathrm{~min}$. Acid phosphatase activity was calculated as the micrograms of $p$-nitrophenyl $(p-\mathrm{NP})$ released per hourper gram root fresh weight.

\subsubsection{Soil enzyme activities}

Acid phosphatase and urease were chosen as indicators of soil capacity to mineralize Po and $\mathrm{N}$ compounds, respectively. Soil acid phosphatase activity was measured using the method described by Rubio et al. (1990) for soil with high organic matter content. Samples of $1 \mathrm{~g}$ in $4 \mathrm{~mL}$ buffer $(0.1 \mathrm{M}$ Tris, $\mathrm{pH}$ 5.5) were incubated with $0.115 \mathrm{M} p$-NPP for $1 \mathrm{~h}$ in a $20{ }^{\circ} \mathrm{C}$ water bath. The reaction was stopped by the addition of $1 \mathrm{~mL}$ of $0.5 \mathrm{M} \mathrm{CaCl}_{2}$, and the mixture was filtered and centrifuged at $2,500 \times \mathrm{g}$ for $10 \mathrm{~min}$. The $p$-NP concentration in the supernatant was measured at $400 \mathrm{~nm}$ in a spectrophotometer. Urease activity was assayed by the modified method of Nannipieri et al. (1980). Four $\mathrm{mL}$ of $0.1 \mathrm{M}$ phosphate buffer ( $\mathrm{pH}$ 7.1) and $1 \mathrm{~mL}$ of $1.067 \mathrm{M}$ urea were added to $1 \mathrm{~g}$ soil samples. The samples were incubated at $20{ }^{\circ} \mathrm{C}$ for 2 $\mathrm{h}$, and thereafter, $5 \mathrm{~mL}$ of $2 \mathrm{M} \mathrm{KCl}$ were added to terminate the reaction. The $\mathrm{N}^{-\mathrm{NH}_{4}}{ }^{+}$was determined by an ion selective electrode.

\subsubsection{Auxin production potential}

To determine the auxin-like substances production potential in the rhizosphere, the method described by Benítez et al. (2004) was used. Two grams of fresh rhizosphere soil (without roots) were aseptically collected and placed in a $50 \mathrm{~mL}$ flask. Six $\mathrm{mL}$ of phosphate buffer ( $\mathrm{pH} 7.5)$ with glucose $(1 \mathrm{~g}$ glucose in $100 \mathrm{ml}^{-1}$ phosphate buffer) and $4 \mathrm{~mL}$ of $4 \mathrm{mM}$ L-tryptophan were added. Soil suspensions were mixed and incubated at $37^{\circ} \mathrm{C}$ for $24 \mathrm{~h}$ in the dark. Two milliliters of $5 \%$ trichloroacetic acid solution to stop the enzymatic conversion of tryptophan to auxin, and $1 \mathrm{~mL}$ of $0.5 \mathrm{M} \mathrm{CaCl}_{2}$ solution was added. An aliquot was transferred to a $1.5 \mathrm{~mL}$ centrifuge tube and centrifuged at 5,000 $\times \mathrm{g}$ for $5 \mathrm{~min}$. Then, a $1-\mathrm{mL}$ aliquot of the supernatant was mixed vigorously with $2 \mathrm{~mL}$ of Salkowski's reagent and allowed to stand at room temperature for $20 \mathrm{~min}$, after which the absorbance at $535 \mathrm{~nm}$ was measured. The concentration of IAAequivalents in each culture medium was determined by comparison with an IAA standard curve.

\subsubsection{Rhizobacterial community composition}

The effect of PMR on the composition of rhizobacterial communities was evaluated by polymerase chain reaction-denaturing gradient gel electrophoresis (PCR-DGGE) of 16S rRNA genes in DNA extracts from the soils. PCR-DGGEwas carried out as described previously by Jorquera et al. (2010). Total DNA was extracted using a Power Soil Soil DNA Isolation Kit (Mo-Bio Laboratories, Inc.), after which 16S rRNA genes were amplified using the primer set EUBf933GC and EUBr1387. The PCR-DGGE analysis was performed in a $9 \%(\mathrm{w} / \mathrm{v})$ polyacrylamide gel with a gradient of $30 \%$ and $55 \%$ (urea and formamide). The electrophoresis was run for $12 \mathrm{~h}$ at $100 \mathrm{~V}$, after which 
the gels were stained with SYBR Gold (Molecular Probes, Invitro gen Co.) for $30 \mathrm{~min}$ and photographed on an UV transilluminator. PCR-DGGE band profiles were compared and dendrograms were generated using Phoretix 1D analysis software (TotalLab Ltd.). Similarities in community composition among samples were calculated by Bray-Curtis method and visualised using non-metric multidimensional scaling (nMDS) utilizing PAST freeware (http://folk.uio.no/ ohammer/past/).

\subsection{Plant biomass and P uptake}

Inoculation of wheat and barley plants with PMR did not significantly $(P \leq 0.05)$ increased the biomass and $\mathrm{P}$ uptake in tissues compared with uninoculated controls (Table 1), except for oat plants inoculated with Enterobacter sp. N0-29PA, which significantly $(P \leq 0.05)$ increased the plant biomass $\left(3.21 \mathrm{~g} \mathrm{pot}^{-1}\right)$ and $\mathrm{P}$ uptake (2.61 $\left.\mathrm{mgpot}^{-1}\right)$ compared with the uninoculated controls $\left(2.49 \mathrm{~g} \mathrm{pot}^{-1}\right.$ and 1.77 mgpot $\left.^{-1}\right)($ Table1).

\section{Results}

Table 1. Effect of phytate-mineralizing rhizobacteria inoculation on plant biomass, $\mathrm{P}$ content and $\mathrm{P}$ uptake of cereal plants without $\mathrm{P}$ fertilization.

\begin{tabular}{|c|c|c|c|}
\hline Wheat & $\begin{array}{l}\text { Plant biomass } \\
\left(\times 10^{-3} \mathrm{~kg} \mathrm{pot}^{-1}\right)\end{array}$ & $\begin{array}{c}\text { P content in tissues } \\
\left(\mathrm{mg} \mathrm{kg}^{-1}\right)\end{array}$ & $\begin{array}{l}\text { P uptake* } \\
\left(\mathrm{mg} \mathrm{pot}^{-1}\right)\end{array}$ \\
\hline Uninoculated control & $2.90 \pm 0.06^{* * *} \mathrm{a}$ & $845 \pm 28 \mathrm{ab}$ & $2.45 \pm 0.11 \mathrm{a}$ \\
\hline Bacillus N1-19NA & $2.33 \pm 0.17 \mathrm{~b}$ & $787 \pm 12 b$ & $1.83 \pm 0.11 \mathrm{~b}$ \\
\hline Enterobacter N0-29PA & $2.76 \pm 0.24 \mathrm{ab}$ & $863 \pm 16 a b$ & $2.39 \pm 0.25 \mathrm{ab}$ \\
\hline Pseudomonas N1-55PA & $2.50 \pm 0.04 \mathrm{ab}$ & $921 \pm 31 \mathrm{a}$ & $2.31 \pm 0.10 \mathrm{ab}$ \\
\hline SerratiaN0-10LB & $2.75 \pm 0.04 \mathrm{ab}$ & $883 \pm 36 \mathrm{ab}$ & $2.43 \pm 0.11 \mathrm{a}$ \\
\hline Oat & $\begin{array}{l}\text { Plant biomass } \\
\left(\times 10^{-3} \mathrm{~kg} \mathrm{pot}^{-1}\right)\end{array}$ & $\begin{array}{c}\text { P content in tissues } \\
\left(\mathrm{mg} \mathrm{kg}^{-1}\right)\end{array}$ & $\begin{array}{l}\text { P uptake* } \\
\left.(\mathrm{mg} \mathrm{pot})^{-1}\right)\end{array}$ \\
\hline Uninoculated control & $2.49 \pm 0.12 b$ & $713 \pm 43 \mathrm{ab}$ & $1.77 \pm 0.14 \mathrm{~b}$ \\
\hline Bacillus N1-19NA & $2.82 \pm 0.16 \mathrm{ab}$ & $759 \pm 31 \mathrm{ab}$ & $2.15 \pm 0.20 \mathrm{ab}$ \\
\hline Enterobacter N0-29PA & $3.21 \pm 0.02 \mathrm{a}$ & $812 \pm 44 a$ & $2.61 \pm 0.15 \mathrm{a}$ \\
\hline Pseudomonas N1-55PA & $2.73 \pm 0.10 \mathrm{~b}$ & $667 \pm 41 \mathrm{~b}$ & $1.83 \pm 0.17 \mathrm{~b}$ \\
\hline SerratiaN0-10LB & $2.74 \pm 0.12 b$ & $745 \pm 21 \mathrm{ab}$ & $2.05 \pm 0.15 \mathrm{ab}$ \\
\hline Barley & $\begin{array}{l}\text { Plant biomass } \\
\left(\times 10^{-3} \mathrm{~kg} \mathrm{pot}^{-1}\right)\end{array}$ & $\begin{array}{l}\text { P content in tissues } \\
\left(\mathrm{mg} \mathrm{kg}^{-1}\right)\end{array}$ & $\begin{array}{l}\text { P uptake* } \\
\left(\mathrm{mg} \mathrm{pot}^{-1}\right)\end{array}$ \\
\hline Uninoculated control & $1.37 \pm 0.09 \mathrm{a}$ & $656 \pm 16 \mathrm{a}$ & $0.89 \pm 0.04 \mathrm{a}$ \\
\hline Bacillus N1-19NA & $1.24 \pm 0.10 \mathrm{a}$ & $659 \pm 22 \mathrm{a}$ & $0.82 \pm 0.08 \mathrm{a}$ \\
\hline Enterobacter N0-29PA & $1.30 \pm 0.15 \mathrm{a}$ & $703 \pm 7$ a & $0.92 \pm 0.11 \mathrm{a}$ \\
\hline Pseudomonas N1-55PA & $1.48 \pm 0.10 \mathrm{a}$ & $698 \pm 14$ a & $1.03 \pm 0.06 \mathrm{a}$ \\
\hline SerratiaN0-10LB & $1.20 \pm 0.01 \mathrm{a}$ & $674 \pm 17 \mathrm{a}$ & $0.81 \pm 0.02 \mathrm{a}$ \\
\hline
\end{tabular}

\footnotetext{
*calculated as P content $\left(\mathrm{mg} \mathrm{kg}^{-1}\right) \times$ Plant dry biomass $\left(\mathrm{kg} \mathrm{pot}^{-1}\right)$

**values represent mean \pm standard error (average of three repeats). Different letters in the same column denote significant difference $(P \leq 0.05)$.
} 


\subsection{Rhizosphere properties}

3.2.1. Phosphorus availability and root surface phosphatase activity

Rhizosphere soil collected from wheat and oat plants inoculated with Enterobacter sp. N0-29PA had significantly $(P \leq 0.05)$ greater available $\mathrm{P}\left(4.8 \mathrm{mg} \mathrm{kg}^{-1}\right.$ in wheat and $3.3 \mathrm{mg} \mathrm{kg}^{-1}$ for oat) than rhizosphere soil from uninoculated plants $\left(2.8 \mathrm{mg} \mathrm{kg}^{-1}\right.$ and $2.7 \mathrm{mg} \mathrm{kg}$ ${ }^{1}$, respectively) (Figure 1, A and B). In contrast, in the same treatments the root phosphatase activities were significantly $(P \leq 0.05)$ lower $\left(907 \mathrm{mg} p-\mathrm{NP} \mathrm{g}^{-1} \mathrm{FW}\right.$ $\mathrm{h}^{-1}$ for wheat and $906 \mathrm{mg} p$-NP g $^{-1} \mathrm{FW} \mathrm{h}^{-1}$ for oat) as compared to the uninoculated controls (1562 $p$-NP g-1 $\mathrm{FW} \mathrm{h}^{-1}$ for wheat and1351 $p$-NP g $\mathrm{g}^{-1} \mathrm{FW} \mathrm{h}^{-1}$ for oat). In oat and barley plants, inoculation with Bacillus sp. N1-19NA also significantly $(P \leq 0.05)$ increased plant available $\mathrm{P}\left(3.25 \mathrm{mg} \mathrm{kg}^{-1}\right.$ and $\left.4.29 \mathrm{mg} \mathrm{kg}^{-1}\right)$ compared to the uninoculated control $\left(2.7 \mathrm{mg} \mathrm{kg}^{-1}\right.$ and $3.5 \mathrm{mg} \mathrm{kg}$ ${ }^{1}$ ) and decreased (937 $p$-NP g ${ }^{-1} \mathrm{FW} \mathrm{h}^{-1}$ and $1718 p$-NP $\left.\mathrm{g}^{-1} \mathrm{FW} \mathrm{h}^{-1}\right)$ the activity of root surface phosphatase compared to the uninoculated controls $(1351 p$-NP g-1 $\mathrm{FW} \mathrm{h}^{-1}$ and $2498 p-\mathrm{NP} \mathrm{g}^{-1} \mathrm{FW} \mathrm{h}^{-1}$ ) (Figure 1, B and C).

\subsubsection{Soil enzyme activities}

Acid phosphatase and urease activities in the rhizosphere were altered by inoculation, with variable responses depending on the plant species and PMR (Table2). In soils containing wheat plants inoculated with Pseudomonas sp. N1-55PA, the acid phosphatase activity was significantly $(P \leq 0.05)$ lower (446 mg $p$-NP g ${ }^{-1}$ soil $^{-1}$ ) compared tothe soils from other treatments (569-683 mg $p$-NP g ${ }^{-1}$ soil $\mathrm{h}^{-1}$ ) and uninoculated controls (614 mg $p$-NP g ${ }^{-1}$ soil h $\mathrm{h}^{-1}$ ). In contrast, the application of the Pseudomonas sp. N155PAto soils planted with oat plants significantly $(P \leq 0.05)$ increased acid phosphatase $(887 \mathrm{mg}$ $p$-NP $\mathrm{g}^{-1}$ soil $\left.\mathrm{h}^{-1}\right)$ and urease $\left(6.65 \mu \mathrm{mol} \mathrm{\textrm {NH } _ { 3 }} \mathrm{g}^{-1}\right.$ soil $\mathrm{h}^{-1}$ ) activities in rhizosphere soil as compared to the uninoculated controls (789 mg $p$-NP $\mathrm{g}^{-1}$ soil

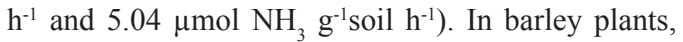
inoculation with Enterobacter sp. N0-29PA resulted ina significant $(P \leq 0.05)$ increase in acid phosphatase activity (703 mg $p-\mathrm{NP} \mathrm{g}^{-1}$ soil h$^{-1}$ ); whereas inoculation with Serratia sp. N0-10LB resulted in a significant $(P \leq 0.05)$ decrease $\left(6.7 \mu \mathrm{mol} \mathrm{NH}_{3} \mathrm{~g}^{-1} \mathrm{Soil} \mathrm{h}^{-1}\right)$ inurease activity compared with uninoculated controls (605 mg $p$-NP $\mathrm{g}^{-1}$ soil $\mathrm{h}^{-1}$ and $8.9 \mu \mathrm{mol} \mathrm{N_{3 }} \mathrm{g}^{-1}$ soil $\mathrm{h}^{-1}$, respectively).

\subsubsection{Auxin production potential}

The potential for auxin production was increasedin the rhizosphere following inoculation with PMR as compared to uninoculated plants. Values for inoculated wheat plants ranged from 6.5-8.4 $\mu \mathrm{g}$ IAA-equivalents $\mathrm{g}^{-1} \mathrm{~h}^{-1}$ as compared to the uninoculated control plants which had $3.7 \mu \mathrm{g}$ IAA-equivalents $\mathrm{g}^{-1} \mathrm{~h}^{-1}$ (Figure 2, A). In oat plants, the treatments with PMR had a higher (10.8-12.8 $\mu \mathrm{g}$ IAA-equivalents $\left.\mathrm{g}^{-1} \mathrm{~h}^{-1}\right)$ auxin production but not significant $(P \leq 0.05)$ compared with uninoculated control $\left(8.4 \mu \mathrm{g}\right.$ IAA-equivalents $\left.\mathrm{g}^{-1} \mathrm{~h}^{-1}\right)$ (Figure 2, B). Similarly to wheat plants, the inoculation of barley plants with Enterobacter sp. N0-29PA, Pseudomonas sp. N1-55PA and Serratiasp. N0-10LB significantly $(P \leq 0.05)$ increased (17.5-19.2 $\mu \mathrm{g}$ IAAequivalents $\left.\mathrm{g}^{-1} \mathrm{~h}^{-1}\right)$ IAA production in the rhizosphere (control $11.3 \mu \mathrm{g}$ IAA-equivalents $\mathrm{g}^{-1} \mathrm{~h}^{-1}$ ) (Figure 2, C). 


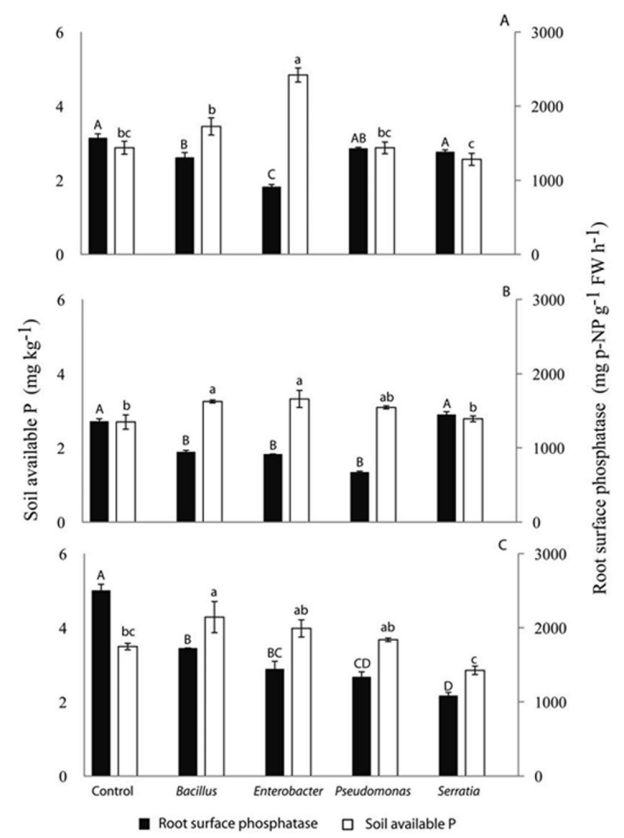

Figure 1. Rhizosphere phosphorus availability and root surface phosphatase activity in A) wheat, B) oat and C) barley plants inoculated with phytate-mineralizing rhizobacteria without $\mathrm{P}$ fertilization. Values represent means \pm standard error ( $n=3$ ). Different upper case (or lower case) letters indicate differences $(P \leq 0.05)$.

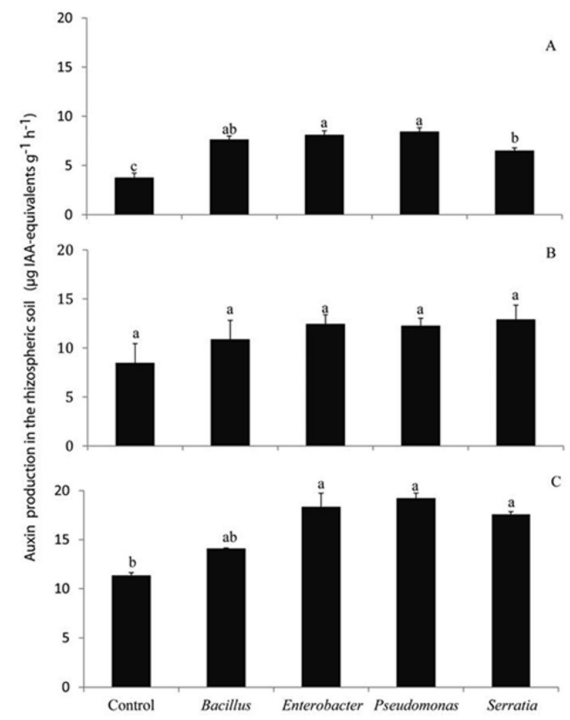

Figure 2. Auxin production potential in the rhizosphere of A) wheat, B) oat and C) barley plants inoculated with phytatemineralizing rhizobacteria without $\mathrm{P}$ fertilization. Values represent mean \pm standard error $(n=3)$. Different letters denote significant difference $(P \leq 0.05)$. 


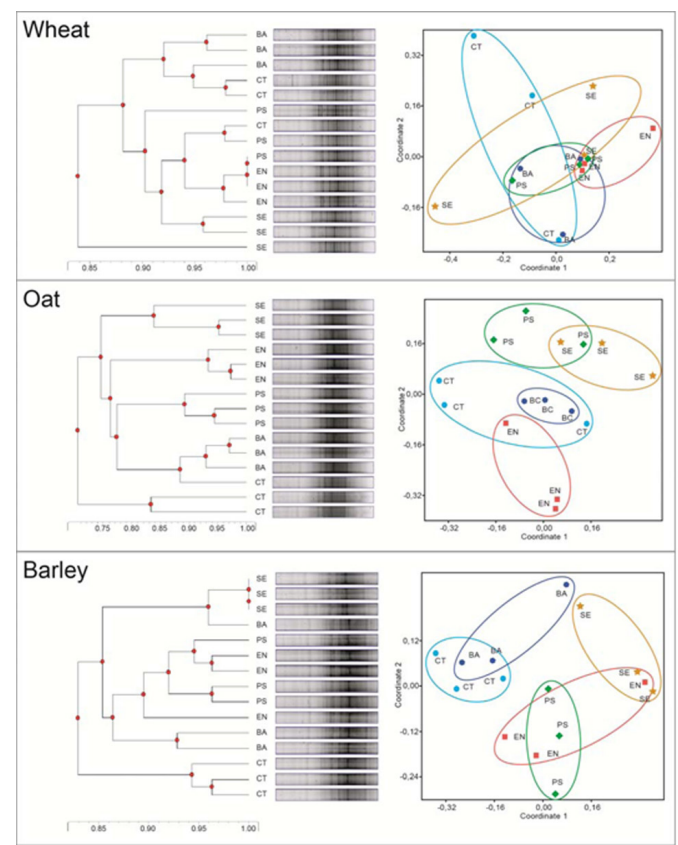

Figure 3. Effect of phytate-mineralizing rhizobacteria on rhizobacterial communities associated with wheat, oat and barley plants without $\mathrm{P}$ fertilization, and visualized as dendrogram and non-metric multidimensional scaling (nMDS) analysis of DGGE profiles (16S rRNA gene).

\subsection{Rhizobacterial community composition}

The dendrograms and nMDS analysis describing the effect of PMR inoculation on compositions of the bacterial communities in the rhizosphere of cereal plants are shown in Figure 3. In wheat, the nMDS analysis did not show any significant change in the bacterial communities of uninoculated and inoculated plants. In contrast, inoculation ofoat plants with either Pseudomonas sp. N1-55PA and Serratia sp. N0-10LB was associated with significant changes in bacterial community structure compared to the uninoculated control orto plants inoculated with Bacillus sp. N119NA and Enterobacter sp. N0-29PA. Likewise, inoculation of barley plants with either Enterobacter sp. N0-29PA, Pseudomonas sp. N1-55PA or Serratias p. N0-10LB induced significant changes compared with the uninoculated control and plants inoculated with Bacillus sp. N1-19NA. In all cases, Bacillus sp. N1-19NA did not produce significant changes in rhizosphere bacterial communities in comparison to the uninoculated control.

\section{Discussion}

In general, this study showed that inoculation with PMR did not consistently enhanced biomass and $\mathrm{P}$ uptake of plants grown in Andisols. These results are similar to those reported by Krey et al. (2011) and Ramírez and Kloepper (2010) for non sterile soil and low P available $\left(<10 \mathrm{mg}\right.$ P available $\mathrm{kg}^{-1}$ soil) conditions. Kreyet al. (2011) did not observe significant effects on the plant growth of maize and oil seed rape by the application of two P-mobilizing 
strains (Pseudomonas fluorescens DR54 and Enterobacter radicincitans DSM 16656) alone and mixed. Ramírez and Kloepper (2010) also did not observe an effect on shoot $\mathrm{P}$ content of Chinese cabbage by phytase-producing bacilli (Bacillus amyloliquefaciens FZB45) inoculation compared with the control. However, our results also showed an increase $(\sim 14 \%)$ in P content in tissues of oat plants inoculated with Enterobacter sp. N0-29PAin PN soil. Moreover, oat plants inoculated with Enterobacter sp. N0-29PA increased significantly the plant biomass ( $29 \%)$ and P uptake ( 47\%) (Table1). These results reveal the potential of Enterobacter sp. N0-29PA as inoculant to improve biomass and $\mathrm{P}$ nutrition of oat plants cultivated in P-deficient soils, such as Chilean Andisols. Assays have showed that inoculation with PSR and PMR (Enterobacter, Pseudomonas and Bacillus) significantly increase the biomass and $\mathrm{P}$ uptake of plants grown in $\mathrm{P}$ deficient soils, even in the absence of $P$ fertilization, suggesting that PSR and PMR may effectively substitute a part of P fertilization (Kumar et al., 2013; Viruel et al., 2014). In many cases, inoculation of plants with PSR or PMR did not result in an increase of the crop parameters monitored. Several actors are attributed to inconsistent performance; one factor receiving increased attention is the effect of inappropriate method for selected PSR based on their ability to solubilization tricalcium phosphates (Bashan et al., 2013).

In relation to $P$ available in the rhizosphere, inoculation with either Bacillussp. N1-19NA or Enterobacter sp. N0-29PA significantly increased the concentrations of $\mathrm{P}_{\text {Olsen }}$ in the rhizosphere as compared to soils inoculated with the other strains or the uninoculated controls (Figure 1). One explanation might be attributed to the phytases that are actively secreted into soil by phytatemineralizing microorganisms, releasing phosphates from fixed Po in soils, which can then be taken up by plants (Richardson and Simpson, 2011). Another explanation could be that $\mathrm{P}$ is released during death and turnover of the bacteria along the older root parts behind the root apices as postulated by Marschner et al. (2011). Investigations have shown that available $\mathrm{P}$ levels can be increased after soil bacterial inoculation (Bacillus megaterium, Pseudomonas striata), but have not investigated the mechanism by which this occurs (Sundara et al., 2002; Viruel et al.,2014). Sundara et al. (2002) showed an increase in $\mathrm{P}_{\text {Olsen }}$ in the rhizosphere of sugarcane inoculated with Bacillus megatherium var. phosphaticum. Still other processes by which bacteria might enhance plant $P$ uptake could involve stimulation of root hair formation, or increased rates of organic acids exudation by microorganisms or plant roots (Richardson and Simpson, 2011). A recent study reports that the inoculation of cattle manure with phytate-mineralizing Bacillus increased the Pi released from phytase-labile P pool contained in the manure, however, applying inoculated manure to soil did not significantly increase yield or P uptake by wheat plants (Menezes-Blackburn et al., 2014).

One of the most interesting observations from this research is the inverse relationship between the level of available $\mathrm{P}$ in the rhizosphere and the phosphatase activity of the roots in plants inoculated with Bacillus sp. N1-19NA and Enterobacter sp. N0-29PA (Figure 1). This phenomenon was previously reported by Paredes et al. (2011), in which they found that the root surface phosphatase was inhibited at least $65 \%$ in response to increased available $\mathrm{P}$ in the rhizosphere. Under P deficiency, it would be hypothesized that the root plants secrete phosphatases to increase $\mathrm{P}$ mobilization in the rhizosphere. However, the regulation of root surface phosphatase activity with respect to plant available $\mathrm{P}$ in the rhizosphere is not yet well understood. Moreover, the possible suppression of this enzyme in the presence of bacteria that putatively enhances $P$ availability requires further explanation. One possibility is that local elevated $\mathrm{P}$ 
contents in the soil may suppress the induction of the surface enzyme activity even while the plant shoot suffers from $P$ deficiency.

In relation to soil enzyme activities in the rhizosphere, inoculation with Pseudomonas sp. N1-55PA increased acid phosphatase and urease activities in the rhizosphere of oat plants (Table 2). This result is in agreement with Mäder et al. (2011) who reported that combined application of Pseudomonas strains ( $P$. jessenii R62 and P. synxantha $\mathrm{R} 81$ ) and arbuscular mycorrhizal fungi increased soil enzyme activities of alkaline phosphatase, acid phosphatase, urease and dehydrogenase in the rhizosphere of wheat. In contrast, inoculation with Pseudomonas sp. N1-55PA decreased acid phosphatase in the rhizosphere of wheat plants (Table 2). This observation also suggets varied effects on soil enzyme activities according to plant types and strains inoculated.

Table 2. The effect of phytate-mineralizing rhizobacteria inoculation on soil enzyme activities of cereal plants without $P$ fertilization.

\begin{tabular}{|c|c|c|c|c|c|}
\hline \multirow[t]{2}{*}{ Parameter } & \multicolumn{5}{|l|}{ Treatments } \\
\hline & Control & $\begin{array}{l}\text { Bacillus } \\
\text { N1-19NA }\end{array}$ & $\begin{array}{l}\text { Enterobacter } \\
\text { N0-29PA }\end{array}$ & $\begin{array}{l}\text { Pseudomonas } \\
\text { N1-55PA }\end{array}$ & $\begin{array}{l}\text { Serratia } \\
\text { N0-10LB }\end{array}$ \\
\hline \multicolumn{6}{|l|}{ Wheat } \\
\hline Acid phosphatase (mg $p$-NP g $\mathrm{g}^{-1}$ soil $^{-1}$ ) & $614 \pm 40^{*} \mathrm{ab}$ & $683 \pm 17$ a & $649 \pm 17.8 \mathrm{ab}$ & $446 \pm 25.7 \mathrm{c}$ & $569.3 \pm 5 b$ \\
\hline Urease $\left(\mu \mathrm{mol} \mathrm{NH}_{3} \mathrm{~g}^{-1}\right.$ soil h $\left.\mathrm{h}^{-1}\right)$ & $4.05 \pm 0.3 \mathrm{ab}$ & $3.38 \pm 0.03 \mathrm{~b}$ & $4.14 \pm 0.17 \mathrm{a}$ & $3.64 \pm 0.01 \mathrm{ab}$ & $3.81 \pm 0,04 \mathrm{ab}$ \\
\hline \multicolumn{6}{|l|}{ Oat } \\
\hline Acid phosphatase (mg $p-\mathrm{NP}^{-1}$ soil $\left.^{-1}\right)$ & $789.1 \pm 12 \mathrm{~b}$ & $824.2 \pm 18$ ab & $836 \pm 0 \mathrm{ab}$ & $887 \pm 27$ a & $832 \pm 10 \mathrm{ab}$ \\
\hline Urease $\left(\mu \mathrm{mol} \mathrm{NH}_{3} \mathrm{~g}^{-1}\right.$ soil $\left.\mathrm{h}^{-1}\right)$ & $5.04 \pm 0.33 \mathrm{~b}$ & $5.02 \pm 0.4 \mathrm{~b}$ & $6.19 \pm 0.37 \mathrm{ab}$ & $6.65 \pm 0.63 \mathrm{a}$ & $6.57 \pm 0.16 \mathrm{a}$ \\
\hline \multicolumn{6}{|l|}{ Barley } \\
\hline Acid phosphatase ( $\mathrm{mg} p-\mathrm{NP}_{\mathrm{g}}{ }^{-1}$ soil $\left.^{-1}\right)$ & $604.7 \pm 6 \mathrm{~b}$ & $601.4 \pm 15 b$ & $702.7 \pm 29 \mathrm{a}$ & $665.5 \pm 6 \mathrm{ab}$ & $632 \pm 9 \mathrm{ab}$ \\
\hline Urease $\left(\mu \mathrm{mol} \mathrm{NH}_{3} \mathrm{~g}^{-1}\right.$ soil $\left.\mathrm{h}^{-1}\right)$ & $8.9 \pm 0.8 \mathrm{a}$ & $8.6 \pm 0.09 \mathrm{ab}$ & $8.5 \pm 0.55 \mathrm{ab}$ & $9.2 \pm 0.24 \mathrm{a}$ & $6.7 \pm 0.16 b$ \\
\hline
\end{tabular}

*values represent mean \pm standard error (average of three repeats). Different letters in the same row denote significant difference $(P \leq 0.05)$.

As expected, inoculation of plants with the PMR strains enhanced the potential production of auxin, indirectly suggesting an effective colonization of the roots by the introduced strains (Figure 2). Production of auxin by rhizobacteria has been suggested as one of the most important factors affecting plant growth and may indirectly affect Puptake by modifying of architecture and morphology of roots or by altering plant root exudation (Marschner et al., 2011). However, in general terms a correlation between auxin productionpotential in the rhizosphere and plant growth was not observed in this study.

One of the most difficult questions in the development of soil inoculants is their interaction with the native rhizosphere microbial community. Bacterial inoculants that are introduced into soils must compete with indigenous rhizobacteria that are well adapted to the local environment. In this research, we found that the compositions of bacterial communities present in the rhizosphere of oat and barley were significantly affected by PMR inoculations (Enterobacter sp.N029PA, Pseudomonas sp. N1-55PA and Serratia sp. N0-10LB) but not in the rhizosphere of wheat (Figure 3). These results are similar to those reported in previously published studies. Grandlic et al. (2009) evaluated the effect of plant growthpromoting bacteria (Clavibacter sp., Rhodanobacter sp. and Arthrobacter sp.) inoculations on Buchloe 
dactyloides rhizosphere microbial community structure. In that work, PCR-DGGE and nMD Sanalysis of the 16S rRNA gene profiles showed that rhizosphere community structures from rhizobacteriainoculated treatments were different from both uninoculated tailings rhizosphere profiles and profiles from the compost used to amend the tailings. Likewise,de-Bashan et al. (2010) reported changes in rhizosphere (Atriplex lentiformis) community structure in response to Azospirillum brasilense Sp6 inoculation by PCR-DGGE analysis. They suggested that soil inoculants not only could persist and stimulate plant growth, but also can directly or indirectly influence rhizobacterial community development. Here we observed inconsistent effects of inoculants on rhizosphere community structure. Inoculation with Bacillus sp.N1-19NA did not cause changes in rhizobacterial community structure for any of the three plants assayed, whereas inoculation with Pseudomonas sp. N1-55PA and Serratia sp. N0$10 \mathrm{LB}$ resulted in shifts in community structures in oat and barley. Many reports suggest that inoculants do not have noticeable effects on community structure using low-resolution methods based on 16S rRNA gene profiles. Herschkovitz et al. (2005) reported that $A$. brasilense inoculation did not alter or disrupt the microbial structure at the group-specific level in maize rhizosphere as revealed by PCR-DGGE finger prints analysis. Likewise, Lerner et al. (2006) reported that no prominent effect of $A$. brasilense inoculation was observed on the bacterial communities of plant roots grown in two different soils by PCR-DGGE and ARISA (automated ribosomal intergenic spacer analysis). Piromyou et al. (2011) inoculated forage corn rhizosphere with Pseudomonas sp. SUT 19 and Brevibacillus sp. SUT 47 and they reported that dominant species in microbial community structure were not altered by PGPR strains.

\section{Conclusions}

The greenhouse experiment conducted here showed that the effects of inoculation with phytatemineralizing rhizobacteria (PMR) were variable depending on the introduced bacterial strain and the cereal plant species. However, the PMR inoculation clearly influenced plant and rhizosphere properties, such plant biomass, $\mathrm{P}$ content in tissues, $\mathrm{P}$ uptake, rootsurface phosphatase activity, phosphorus availability, auxin production potential, and soil enzyme activities. Particularly, Enterobacter N0-29PA significantly increased plant biomass and Puptake of oat plants in volcanic soil without $\mathrm{P}$ fertilization. However, the evaluation of Enterobacter N0-29PA as a complement to or partial substitute for $\mathrm{P}$ fertilization in cultivated Andisol requires major studies and analysis before recommendations can be made for its use as a biofertilizer. In addtion, PMR inoculation induced substantial changes in rhizobacterial community composition as revealed by polymerase chain reaction-denaturing gradient gel electrophoresis (PCR-DGGE) and non-metric multidimensional scaling (nMDS) analysis. This result shows that PMR application substantially modified the bacterial communities in the rhizosphere. However, longterm studies are required to confirm if these changes are maintained by PMR inoculants at field level in Chilean Andisols.

\section{Acknowledgements}

This study was financed by FONDECYT no.1120505 and 1141247. O.A. Martínezalso acknowledges the support of CONICYT Ph.D. Scholarship no. 21070354 and FONDECYT no. 11130352. 


\section{References}

Acuña, J.J., Jorquera, M.A., Martínez, O.A., MenezesBlackburn, D., Fernández, M.T., Marschner, P., Greiner, R., Mora, M.L. 2011. Indole acetic acid and phytase activity produced by rhizosphere bacilli as affected by $\mathrm{pH}$ and metals. J. Soil Sci. Plant Nutr. 11(3), 1-12.

Bashan, Y., Kamnev, A.A., de-Bashan, L.E. 2013. Tricalcium phosphate is inappropriate as a universal selection factor for isolating and testing phosphate-solubilizing bacteria that enhance plant growth: a proposal for an alternative procedure. Biol.Fertil. Soils 49, 465-479.

Benítez, E., Melgar, R., Nogales, R. 2004. Estimating soil resilience to a toxic organic waste by measuring enzyme activities. Soil Biol.Biochem. $36,1615-1623$.

Borie, F., Rubio, R. 2003. Total and organic phosphorus in Chilean volcanic soils. Gayana Bot. 60, 69-78.

de-Bashan, L.E., Hernandez, J.P., Nelson, K.N., Bashan, Y., Maier, M. 2010.Growth of quailbush in acidic, metalliferous desert mine tailings: effect of Azospirillum brasilense Sp 6 on biomass production and rhizosphere community structure. Microb. Ecol. 60, 915-927.

Fernández, L.A., Zalba, P., Gómez, M.A., Sagardoy, M.A. 2007. Phosphate-solubilization activity of bacterial strains in soil and their effect on soybean growth under greenhouse conditions. Biol.Fertil. Soils. 43, 805-809.

Grandlic, C.J., Palmer, M.W., Maier, R.M. 2009. Optimization of plant growth-promoting bacteriaassisted phytostabilization of mine tailings. Soil Biol.Biochem. 41, 1734-1740.
Herschkovitz, Y, Lerner, A., Davidov, Y., Okon, Y., Jurkevitch, E. 2005. Azospirillum brasilense does not affect population structure of specific rhizobacterial communities of inoculated maize (Zea mays). Environ. Microbiol. 7, 1847-1852.

Jorquera, M., Hernández, M., Rengel, Z., Marschner, P., Mora, M.L. 2008. Isolation of culturable phosphor bacteria with both phytatemineralization and phosphate-solubilization activity from the rhizosphere of plants grown in a volcanic soil. Biol. Fertil. Soils. 44, 1025-1034.

Jorquera, M.A., Hernández, M.T., Martínez, O., Marschner, P., Mora, M.L. 2010. Detection of aluminium tolerance plasmids and microbial diversity in the rhizosphere of plants grown in acidic volcanic soil. Eur. J.Soil Biol. 46, 255-263.

Jorquera, M.A., Crowley, D.E., Marschner, P., Greiner, R., Fernández, M.T., Romero, D., MenezesBlackburn, D., Mora, M.L. 2011. Identification of $\beta$-propeller phytase-encoding genes in culturable Paenibacillus and Bacillus spp. from the rhizosphere of pasture plants on volcanic soils. FEMS Microbiol. Ecol. 75,163-172.

Krey, T., Caus, M., Baum, C., Ruppel, S., EichlerLöbermann, B. 2011. Interactive effects of plant growth-promoting rhizobacteria and organic fertilization on P nutrition of Zea mays L. and Brassica napus L. J. Plant Nutr. Soil Sci. 174, 602-613.

Kumar, V., Singh, P., Jorquera, M.A., Sangwan, P., Kumar, P., Verma, A.K., Agrawal, S. 2013. Isolation of phytase-producing bacteria from Himalayan soils and their effect on growth and phosphorus uptake of Indian mustard (Brassica juncea). World J. Microbiol.Biotechnol. 29, 1361-1369. 
Lerner, A., Herschkovitz, Y., Baudoin, E., Nazaret, S., Moenne-Loccoz, Y., Okon, Y., Jurkevitch, E. 2006. Effect of Azospirillum brasilense inoculation on rhizobacterial communities analyzed by denaturing gradient gel electrophoresis and automated ribosomal intergenic spacer analysis. Soil Biol.Biochem. 38, 1212-1218.

Mäder, P., Kaiser, F., Adholeya, A., Singh, R., Uppal, H.S., Sharma, A.K., Srivastava, R., Sahai, V., Aragno, M., Wiemken, A., Johri, B.N., Fried, P.M. 2011. Inoculation of root microorganisms for sustainable wheat-rice and wheat-black gram rotations in India. Soil Biol. Biochem. 43, 609619.

Marschner, P., Crowley, D., Rengel, Z. 2011. Rhizosphere interaction between microorganisms and plants govern iron and phosphorus acquisition along the root axis - model and research methods. Soil Biol. Biochem. 43, 883-894.

Martínez, O.A., Jorquera, M.A., Crowley, D.E., Mora, M.L. 2011.Influence of nitrogen fertilisation on pasture culturable rhizobacteria occurrence and the role of environmental factors on their potential PGPR activities. Biol.Fertil.Soils. 47, 875-885.

Menezes-Blackburn, D., Jorquera, M.A., Greiner, R., Gianfreda, L., Mora, M.L. 2013. Phytases and phytase-labile organic phosphorus in manures and soils. Crit. Rev. Environ. Sci. Technol. 43, 916-954.

Menezes-Blackburn, D., Jorquera, M.A., Gianfreda, L., Greiner, R., Mora, M.L. 2014. A novel phosphorus biofertilization strategy using cattle manure treated with phytase-nanoclay complexes. Biol.Fertil.Soils. 50, 583-592.
Mora, M.L., Canales, J. 1995. Humin-clay interactions on surface reactivity in Chilean Andisols. Commun. Soil Sci. Plant Anal. 26, 2819-2828.

Nannipieri, P., Ceccanti, B., Cervelli, S., Matarese, E. 1980. Extraction of phosphatase, urease, protease, organic carbon, and nitrogen from soil. Soil Sci. Soc. Am. J.44, 1011-1016.

Paredes, C., Menezes-Blackburn, D., Cartes, P., Gianfreda, L., Mora, M.L. 2011. Phosphorus and nitrogen fertilization effect on phosphorus uptake and phosphatase activity in ryegrass and tall fescue grown in a Chilean Andisol. Soil Sci. 176, 245-251.

Piromyou, P., Buranabanyat, B., Tantasawat, P., Tittabutr, P., Boonkerd, N., Teaumroong, N. 2011. Effect of plant growth promoting rhizobacteria (PGPR) inoculation on microbial community structure in rhizosphere of forage corn cultivated in Thailand. Eur. J. Soil Biol. 47, 44-54.

Ramírez, C.A., Kloepper, J.W. 2010. Plant growth promotion by Bacillus amyloliquefaciens FZB45 depends on inoculum rate and P-related soil properties. Biol.Fertil. Soils. 46, 835-844.

Richardson, A.E., Simpson, R.J. 2011. Soil microorganisms mediating phosphorus availability. Plant Physiol. 156, 989-996.

Rubio, R., Moraga, E., Borie, F. 1990. Acid phosphatase activity and vesicular-arbuscular mycorrhizal infection associated with roots of four wheat cultivars. J. Plant Nutr. 13, 585-598.

Sadzawka, A., Carrasco, M., Grez, R., Mora, M.L., Flores, H., Neaman, A. 2006. Métodos de análisis recomendados para los suelos de Chile. Instituto de Investigación Agropecuaria. Serie Actas INIA No34. INIA. Santiago, Chile, 164p. 
Sadzawka, A., Grez, R., Carrasco, M., Mora, M. 2007. Métodos de análisis de tejidos vegetales, CNA Comisión de Normalización y Acreditación. Sociedad Chilena de la Ciencia del Suelo, Santiago, Chile, 53p.

Sundara, B., Natarajam, V., Hari, K. 2002. Influence of phosphorus solubilizing bacteria on the changes in soil available phosphorus and sugarcane and sugar yields. Field Crops Res. 77, 43-49.
Viruel, E., Erazzú, L.E., Martínez Calsina, L., Ferrero, M.A., Lucca, M.E., Siñeriz, F. 2014. Inoculation of maize with phosphate solubilizing bacteria: effect on plant growth and yield. J. Soil Sci. Plant Nutr. 14 (4), 819-831. 